\title{
SKIN AND SKELETAL SYSTEM LESIONS OF EUROPEAN POND TURTLES (EMYS ORBICULARIS) FROM NATURAL HABITATS
}

\author{
Sanja AleKsiĆ-KovaČEviĆ ${ }^{1}$, József ÖZVVEGY ${ }^{2}$, Nikola KrSTIĆ ${ }^{3}$, Miklós RUSVAI ${ }^{4}$, \\ Csaba JAKAB ${ }^{4}$, Zoran STANIMIROVIĆ ${ }^{5}$ and Zsolt BECSKEI ${ }^{6 *}$ \\ ${ }^{1}$ Department of Pathology, Faculty of Veterinary Medicine, University of Belgrade, \\ Belgrade, Serbia; ${ }^{2}$ Belgrade Zoo Garden, Belgrade, Serbia; ${ }^{3}$ Department of Radiology \\ and Radiotherapy, Faculty of Veterinary Medicine, University of Belgrade, Belgrade, \\ Serbia; ${ }^{4}$ Department of Pathology and Forensic Veterinary Medicine, Faculty of \\ Veterinary Science, Szent István University, Budapest, Hungary; ${ }^{5}$ Department of \\ Biology, Faculty of Veterinary Medicine, University of Belgrade, Belgrade, Serbia; \\ ${ }^{6}$ Department of Animal Breeding and Genetics, Faculty of Veterinary Medicine, \\ University of Belgrade, Bulevar Oslobodenja 18, 11000, Belgrade, Serbia
}

(Received 23 October 2012; accepted 2 July 2013)

Water pollution is known to play an important role in the pathogenesis of plastron, carapace and skin diseases of turtles. In this study, a total of 150 European pond turtles (Emys orbicularis) of different age and both sexes, originating from natural habitats in Serbia, were examined for morphological changes of the skin, plastron, carapace and skeletal system. The turtles were taken out from their natural habitats in Lake Ludas, Lake Palic and Lake Tresetiste. After artificial hibernation, they were subjected to detailed examination, sampled and treated, and finally returned into their natural habitat. Biopsies from the skin and shell were subjected to histopathological examination and microbiological analysis. X-ray scanning was also performed to detect changes in the skeletal system. Macroscopic changes of the skin, most frequently degenerative, inflammatory or neoplastic diseases, were diagnosed in $49.33 \%$ of the turtles examined. Dermatitis of different origin and form was the most prominent histopathological finding $(28.00 \%)$. In the plastron, inflammatory and degenerative processes were frequently found. Osteopathy and mechanical injuries were the dominant findings. Macroscopic changes of the plastron, carapace and skeletal system were diagnosed in $67.33 \%$ of the turtles examined. Using X-ray scanning, generalised osteopathy, anomalies and malformations of different aetiology were also diagnosed on the tail and legs. Microbiological examinations showed the presence of a variety of bacterial and fungal agents, either primary pathogens or potential polluters, which invaded the skin and shell, or were present in cloacal swab samples. Bacterial infection was diagnosed in $76.66 \%$ of the turtles, first of all in those with skin and shell necrosis. Mycoses were diagnosed in $33.33 \%$ of the animals.

Key words: Emys orbicularis, pond turtle, skin and skeletal system, water pollution

\footnotetext{
"Corresponding author; E-mail: beckeizolt@gmail.com; Phone: 00381 (659) 911-101
} 
The European pond turtle (Emys orbicularis) is the only protected turtle species in Serbia, which inhabits still waters, such as lakes and ponds rich in aquatic vegetation. European pond turtles live in the regions of Northwest Africa, Southern Europe and Asia up to the Lake Aral and in Eastern Europe, all the way up to the Baltic Sea (Mitrus, 2006; Ficetola and De Bernardi, 2006).

Although the lifespan of European pond turtle may be affected to some extent by climate changes, road networks often exert complex ecological effects on animal populations, such as fragmenting natural habitats and creating barriers for animal movement (Trakimas and Sidaravicius, 2008). Environmental contamination of the natural habitat, primarily through waste water discharges, has an important role in the development of various pathological changes in reptiles, including the protected turtle species Emys orbicularis in the region of Northern Vojvodina (Ezvedj, 2005). External inputs of nutrient-rich (nitrogen and phosphorus) and polluted waters are the major causes of eutrophication and water pollution in Lakes Palic and Ludas. Today, Lake Palic is intensively used as a recipient for treated sewage water of the city of Subotica and it does not have an adequate recharge with water of acceptable quality. This has led to high phytoplankton biomass, turbid water and often undesired biological changes. The latter includes loss of biodiversity, disappearance of submerged macrophytes and changes in population of fish and reptiles (Scheren et al., 2000; Sondergaard et al., 2003). Results of analysis of water quality of Lake Palic in 2010 showed a presence of polluters in high concentration: chloride $163.7 \mathrm{mg} / \mathrm{l}$, sulphate $434.5 \mathrm{mg} / \mathrm{l}$, orthophosphate $1.39 \mathrm{mg} / \mathrm{l}$, total phosphorus $1.46 \mathrm{mg} / \mathrm{l}$, total nitrogen $7.93 \mathrm{mg} / \mathrm{l}$ and total organic carbon $9.80 \mathrm{mg} / 1$ (Raičević et al., 2011).

Reptiles, among them turtles, are diagnosed with different skin and bone lesions (Mader, 2006) as well as with tumours at an increasing rate (Gál et al., 2006; Gál et al., 2009; Gál et al., 2010). According to Garner et al. (2004), fibropapilloma (34.4\%) and squamous cell carcinoma (10.30\%) are the most common types of skin tumours. The most common systemic diseases in reptiles arise as a consequence of impaired mineral and vitamin D metabolism. The initial stages of these disorders are very often unrecorded, as they are manifested mainly as apathy and impaired locomotion which remain unnoticed in free-living turtles. Metabolic bone disease (MBD) is a well-recognised and common disease of reptiles. Other terms which may be used include fibrous osteodystrophy, osteomalacia, secondary nutritional hyperparathyroidism, osteoporosis and rickets. There is no single cause and the disease is not a simple calcium deficiency. However, the primary problem is a disruption of calcium metabolism which causes a host of related problems (Mader, 1990). Fractures most often involve the long bones, but jaw fractures are not rare either. All reptiles, including turtles, have a pronounced callus formation which develops at a slower rate when compared with other animal species. Fractures of the turtle's shell show characteristic features that require a particular review of this protective organ (Mader, 1990). Spontaneous 
fractures of the shell have been reported in cases of rickets and osteoporosis (Frye, 1991; Frye, 1994).

Based on a long-term monitoring of the health status of this protected species, 150 European pond turtles from natural habitats were analysed. In most cases inflammatory skin and bone lesions as well as metabolic bone lesions were detected and described, with neoplastic diseases being reported in some instances. The occurrence of some of these lesions was possibly related to ecological changes such as water pollution. As mentioned, both polluted water and eutrophication are present in Lakes Palic and Ludas (Raičević et al., 2011).

\section{Materials and methods}

\section{Animals and collection}

In the present study, a total of 150 adult European pond turtles (Emys orbicularis) of 7 to 14 years of age, and of both sexes including 97 females and 53 males, were examined. Turtles were taken from their natural habitat at three separate locations from early spring to late autumn. Sixty turtles were examined from Lake Ludas, eighty turtles from Lake Palic and ten turtles from the artificial lake Tresetiste. All of these habitats are located in the region of Northern Vojvodina, Republic of Serbia. The Lake Palic is a shallow Pannonian lake, situated $8 \mathrm{~km}$ from Subotica and having a covering area of $4.6 \mathrm{~km}^{2}$. Excess water from Lake Palic is evacuated via a canal to the Lake Ludas. Lake Ludas is located $3 \mathrm{~km}$ east from Lake Palic, covering an area of $3.8 \mathrm{~km}^{2}$ and it is connected by the Keres streamlet to the Tisza River. Tresetiste is the north branch of Keres, located 12 $\mathrm{km}$ north-east of Subotica, and it covers $0.04 \mathrm{~km}^{2}$. It is located close to the Hungarian border and there are no present settlements in the neighbourhood which could pollute this natural habitat.

Turtles were captured using special cages. After capture, the animals were placed in thermo boxes at $4-8{ }^{\circ} \mathrm{C}$ for one hour, which provided a stage of artificial hibernation important for further examination. Different morphometric data were collected [carapace length (CL) and width (CW), plastron length (PL) and width (PW), height $(\mathrm{H})$ and body mass]. Approximate age was estimated using morphometric data. Mass was recorded using a triple-beam to the nearest gram, and linear dimensions were recorded with fabric tape to the nearest $\mathrm{mm}$. Each turtle was marked with a unique identification number with stamping on marginal scutes (Holland, 1994). After clinical investigation, which included inspection and palpation as well as detailed macroscopic examination of the plastron and carapace, swabs of the skin, shell and cloaca were taken for microbiological analysis. The turtles were scanned using X-ray. For histopathological examination, biopsy samples were obtained in local anaesthesia, using subcutaneous injection of lidocaine $(1 \mathrm{mg} / \mathrm{kg})$ at the incision site. Investigation was done accord- 
ing to the Animal Welfare Act and permission of the Institute for Nature Conservation of Serbia and the examined turtles were returned to the same habitat, taking into consideration the fact that they belong to a protected animal species.

\section{Radiology}

Radiographs were taken of artificially hibernated turtles in order to minimise movements and struggling. The radiographs were taken in ventrodorsal projection, with parameters of $35 \mathrm{KV}, 20 \mathrm{~mA}$ and $\mathrm{Ffo} 60 \mathrm{~cm}$. The central X-ray was perpendicular to the subject recorded. Standard format cassettes $(30 \times 40 \mathrm{~cm}$ and $24 \times 30 \mathrm{~cm}$ ) with gadolinium foils were used.

\section{Histopathology}

Tissue samples were collected for histopathological examination. The bone samples were decalcified in $80 \%$ formic acid for $48 \mathrm{~h}$ prior to formalin fixation and the skin samples were fixed directly in $10 \%$ neutral formalin for $24-48 \mathrm{~h}$. After fixation, the tissues were processed in an automated tissue processor, and embedded into paraffin blocks. For light microscopic examination, 3- to 5- $\mu \mathrm{m}$ thick slices were stained with haematoxylin and eosin (HE) and with periodic acid-Schiff (PAS) methods.

\section{Microbiology}

For microbiological examination, swabs were collected from the skin, plastron, carapace and cloaca, and then streaked on two sets of nonselective and selective media such as blood agar, MacConkey agar, thiogluconate medium and nutrient broth (Oxoid, UK). One set of the inoculated media was incubated at $27 \pm$ $1{ }^{\circ} \mathrm{C}$, the other one at $37 \pm 1{ }^{\circ} \mathrm{C}$ up to $48 \mathrm{~h}$. Bacterial growth was first inspected after $24 \mathrm{~h}$ of incubation, then at the end of the incubation period. The observed colonies were subcultured on blood agar in order to get clear cultures for identification. Following incubation, isolates were submitted to tests for presumptive identification (Gram staining, morphology, oxidase test, catalase test, motility test, oxidation/fermentation test, growth on MacConkey agar). In the case of members of the Enterobacteriaceae family, identification was completed using the API 20E kit (BioMérieux, France). Other Gram-negative rods were identified with API 20 NE kit (BioMérieux, France). Swabs from shell surface were also subject of mycological investigation. Inoculated Sabouraud dextrose agar plates (Oxoid, UK ) were incubated at $25 \pm 1{ }^{\circ} \mathrm{C}$ up to 7 days, with inspecting them daily after $72 \mathrm{~h}$ of incubation. Mould colonies were identified to the genus level according to their macroscopic and microscopic morphological characteristics. Cloacal swabs served for the isolation of Salmonella spp. Samples were inoculated in buffered peptone water (BPW, Oxoid, UK) and incubated at $37 \pm 1{ }^{\circ} \mathrm{C}$ for $18 \pm 1 \mathrm{~h}$. After the incubation period, $0.1 \mathrm{ml}$ of BPW was inoculated on the 
surface of modified semi-solid Rappaport-Vassiliadis agar (MSRV, Oxoid, UK), and $1 \mathrm{ml}$ of BPW was inoculated in $10 \mathrm{ml}$ of Müller-Kauffman tetrathionate novobiocin broth. MSRV plates were incubated at $41.5 \pm 1{ }^{\circ} \mathrm{C}$ and tetrathionate broth at $37 \pm 1{ }^{\circ} \mathrm{C}$. Rambach agar (Merck, Germany) and xylose lysine desoxycholate agar (XLD, Oxoid, UK) were used as differential media. These media were streaked with inoculum from MSRV after 24 and $48 \mathrm{~h}$ of incubation, and from tetrathionate broth after $24 \mathrm{~h}$ of incubation. Rambach and XLD agars were incubated for $24 \mathrm{~h}$ at $37 \pm 1{ }^{\circ} \mathrm{C}$. Suspect colonies from differential agar plates were inoculated on TSI agar (Oxoid, UK) for preliminary identification. Identification of Salmonella spp. was confirmed by API 20E kit (BioMérieux, France).

\section{Results}

Skin lesions were the most prominent macroscopic findings in the turtles examined (Table 1). Macroscopic skin lesions of different form and origin were observed in $73(48.67 \%)$ of the turtles examined (Figs 1A, 1B, 1C). The most common macroscopic lesions found on the skin of turtles were abscesses and dermatitis, regerenative changes, cutaneous ulcerative disease, keratin layer abruption, blepharoconjunctivitis, and pododermatitis.

Table 1

Most common macroscopic changes found on the skin of European pond turtles from different natural habitats

\begin{tabular}{lccc}
\hline Finding & $\begin{array}{c}\text { Lake Ludas } \\
(\mathrm{n}=60)\end{array}$ & $\begin{array}{c}\text { Lake Palic } \\
(\mathrm{n}=80)\end{array}$ & $\begin{array}{c}\text { Lake Tresetiste } \\
(\mathrm{n}=10)\end{array}$ \\
\hline Keratin layer abruption & $2 / 60$ & $7 / 80$ & $1 / 10$ \\
Regenerative changes & $5 / 60$ & $10 / 80$ & $1 / 10$ \\
Abscesses & $2 / 60$ & $5 / 80$ & $0 / 10$ \\
Invasion of the skin with algae & $3 / 60$ & $7 / 80$ & $0 / 10$ \\
Dermatitis & $3 / 60$ & $10 / 80$ & $0 / 10$ \\
Septicaemic cutaneous ulcerative disease & $2 / 60$ & $5 / 80$ & $0 / 10$ \\
Oedema of subcutis & $2 / 60$ & $4 / 80$ & $0 / 10$ \\
Tumour & $0 / 60$ & $2 / 80$ & $0 / 10$ \\
Local leukoderma & $2 / 60$ & $2 / 80$ & $0 / 10$ \\
Pododermatitis with necrosis of phalanges & $1 / 60$ & $2 / 80$ & $0 / 10$ \\
Blepharoconjunctivitis & $2 / 60$ & $3 / 80$ & $0 / 10$ \\
Turtles with no lesion & $35 / 60$ & $33 / 80$ & $9 / 10$ \\
\end{tabular}

Microscopic examination of skin revealed a variety of histopathological changes in $93(62 \%)$ of the turtles examined (Table 2), while in 57 turtles $(38 \%)$ pathological changes were not observed. The skin lesions had different manifestations. The most common finding was a dermatitis of different aetiology, diag- 
nosed in 42 turtles (28\%), occurring mainly in purulent-like form. Degenerative or regenerative skin lesions were detected in 33 turtles (22\%) (Fig. 2A). Necrotic and gangrenous changes were seen in 24 turtles $(12 \%)$. In most animals with dermatitis, microscopic changes were seen in the form of intensive infiltration with polymorphonuclear cells, predominantly heterophilic granulocytes (Fig. 2C). Necrotic tissue debris accumulation was sometimes accompanied by the presence of numerous nucleated erythrocytes (Fig. 2B).

Different lesions were observed on the plastron, carapace and in the skeletal system of $101(67.33 \%)$ turtles (Table 3). A total of 89 turtles $(59.33 \%)$ had lesions on the shell. Necrosis of the plastron was seen in 32 animals (21.33\%) (Fig. 2E). In some cases the keratin layer was separated from the bone matrix. Limb and tail anomalies were seen in 16 turtles (10.67\%) and traumatic lesions in 4 animals $(2.67 \%$ ) (Figs 1D, 1E). Osteoporosis was also diagnosed in some of the turtles examined (4\%). Agglomeration of algae on the shell was detected in 18 turtles (12\%). In terms of neoplastic lesions, chondroma was observed in the tarsal joint area of one turtle and adenoma was seen in the lacrimal gland of another animal (Fig. 2D).

Using radiography, metabolic osteopathy, degenerative and proliferative changes and traumatic lesions were also diagnosed. Generalised osteoporosis, manifested as atrophy of bone tissue was evident on histological sections (Fig. 2F), as well as on ventrodorsal radiographs of the affected turtle's shell. The most evident change of bone tissue macrostructure was the granular and marbled appearance of the vertebral and costal scutes, while the marginal ones retained a more condensed structure. Radiographic imaging showed reduction of bone tissue prominent on a thoracic vertebra in the region of the spinous process. The outlines of the vertebrae were unclear, but the shape of each was preserved. The trabeculae of the spongy bone tissue were enlarged due to ongoing bone tissue rarefaction. This finding corresponds to osteoporosis of the turtle's shell, and was diagnosed in 6 turtles (4\%). Radiographs have revealed a clear sign of osteoporosis, as the carapace showed decalcified macrostructures and a weak marbled shadow of the spongy bone tissue. In the central areas of the scutes, oblique and rounded opaque spots could be seen, which gave the scutes an unclear cloudy appearance. The outer margins were not intensive, and were fragmented with early signs of turning into spongy structures. Concerning traumatic lesions, shell fractures were evident in four turtles $(2.66 \%)$. On the ventrodorsal radiographs of a turtle's shell a transversal irregular fracture line was clearly visible. In one case, due to forces of compression, there were two thin $\mathrm{V}$-shaped fracture lines on the junction between the plastron and the carapace. In the abdomen of a turtle with fracture, the outlines of six egg shells were also present. The described image corresponds to the diagnosis of shell fracture in the turtle examined (Fig. 1F). 


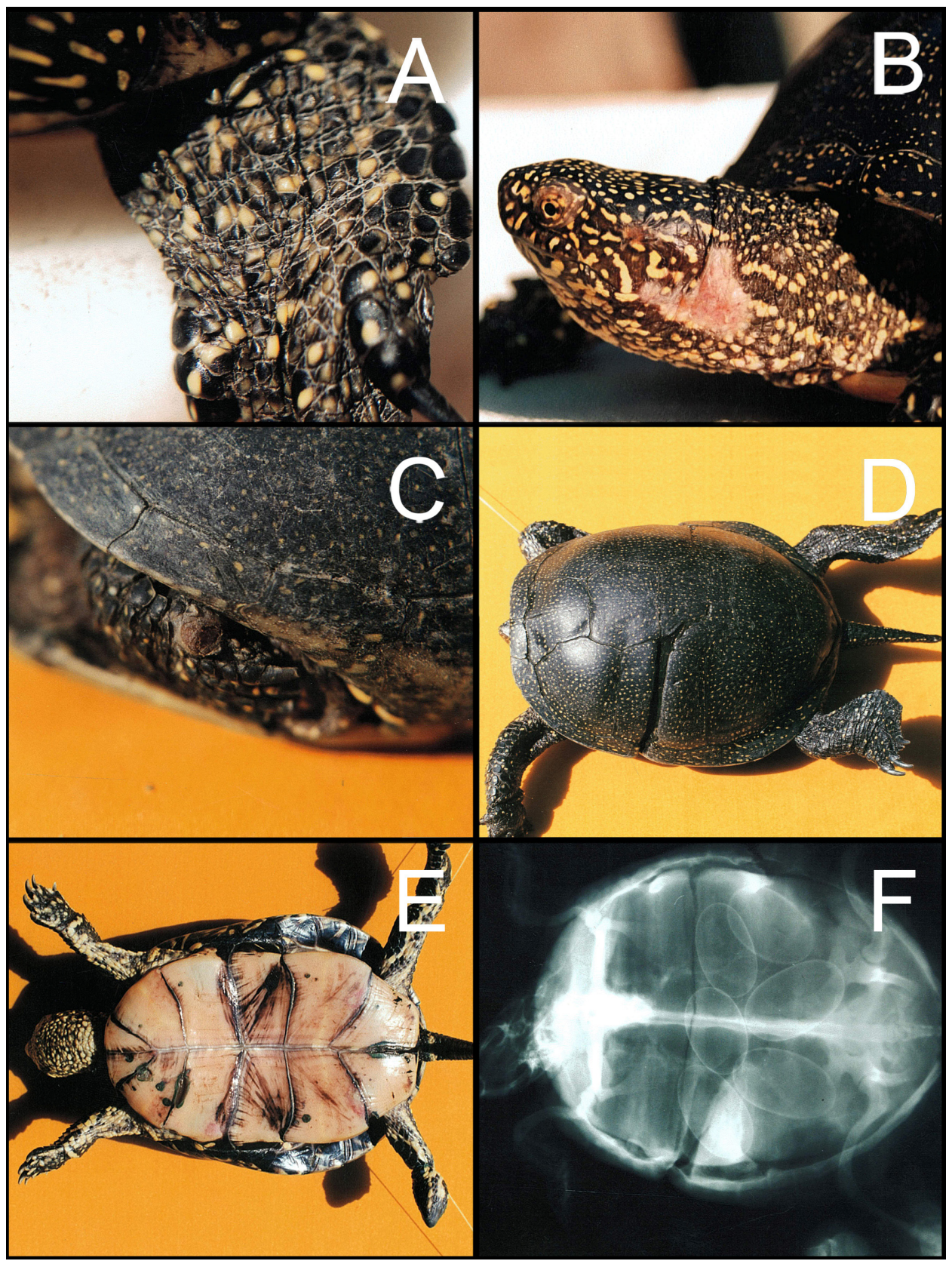

Fig. 1A. Normal skin of a pond turtle with prominent scales. $B$. Regeneration of the skin at the site of a mechanical lesion. $C$. Abscess of the skin. $D$. Healing process of the fractured carapace. $E$. Aplasia of the phalanges on the hind leg. $F$. Fracture lines on the junction between the plastron and the carapace. The outlines of six egg shells are present in the abdomen 
Table 2

Most common histopathological lesions of the skin of European pond turtles from different natural habitats

\begin{tabular}{|c|c|c|c|}
\hline Finding & $\begin{array}{l}\text { Lake Ludas } \\
\qquad(\mathrm{n}=60)\end{array}$ & $\begin{array}{l}\text { Lake Palic } \\
\quad(\mathrm{n}=80)\end{array}$ & $\begin{array}{l}\text { Lake Tresetiste } \\
\qquad(\mathrm{n}=10)\end{array}$ \\
\hline Necrosis with hyalinisation & $3 / 60$ & $5 / 80$ & $0 / 10$ \\
\hline Process of regeneration & $5 / 60$ & $10 / 80$ & $3 / 10$ \\
\hline Necrosis with petrification & $0 / 60$ & $3 / 80$ & $0 / 10$ \\
\hline Leukoderma & $5 / 60$ & $10 / 80$ & $0 / 10$ \\
\hline Purulent-like dermatitis & $4 / 60$ & $11 / 80$ & $0 / 10$ \\
\hline Non-purulent-like dermatitis & $6 / 60$ & $16 / 80$ & $0 / 10$ \\
\hline Dry gangrene & $3 / 60$ & $2 / 80$ & $0 / 10$ \\
\hline Haemorrhagic necrosis & $3 / 60$ & $5 / 80$ & $0 / 10$ \\
\hline Oedema of the subcutis & $4 / 60$ & $4 / 80$ & $0 / 10$ \\
\hline Lacrimal gland adenoma & $0 / 60$ & $1 / 80$ & $0 / 10$ \\
\hline Turtles with no histopathological lesions & $32 / 60$ & $18 / 80$ & $7 / 10$ \\
\hline
\end{tabular}

Regarding the degenerative changes and anomalies, in some turtles severe changes were evident on the front and hind legs (Fig. 1E). The shape, size and number of bone structures were altered. The absence of metacarpal bones III, IV and V was evident, while metacarpal bones I and II were hypoplastic with subsequently altered joint surfaces.

By microbiological examination of swabs different microorganisms were isolated from 115 turtles (76.67\%). Aeromonas hydrophila (74\%), Citrobacter freundi (41.33\%), Serratia sp. (65.33\%) and Escherichia coli (65.33\%) were present both on the shell and the skin. Bacillus sp. (54\%), Enterobacter sp. (50\%) and Klebsiella sp. (32\%) were isolated only from the skin, while Proteus sp. $(76.67 \%)$ and Pseudomonas chitinovora $(38.67 \%)$ were isolated from the shell. In $28.67 \%$ of the tested cloacal swabs Salmonella sp. was isolated. Mucor sp. $(25.33 \%)$ and less often Fusarium sp. (8.00\%) were isolated from swab samples taken from the shell of the turtles examined.

\section{Discussion}

Establishing an accurate diagnosis of diseases in turtles is extremely difficult due to their elusive way of life and specific body anatomy, as the greatest part of the body is covered by a tough shell. In the present study, a total of 150 adult European pond turtles (Emys orbicularis), the only protected water turtle species in Serbia, aged 7 to 14 years and of both sexes (comprising 97 females and 53 males), were examined. 


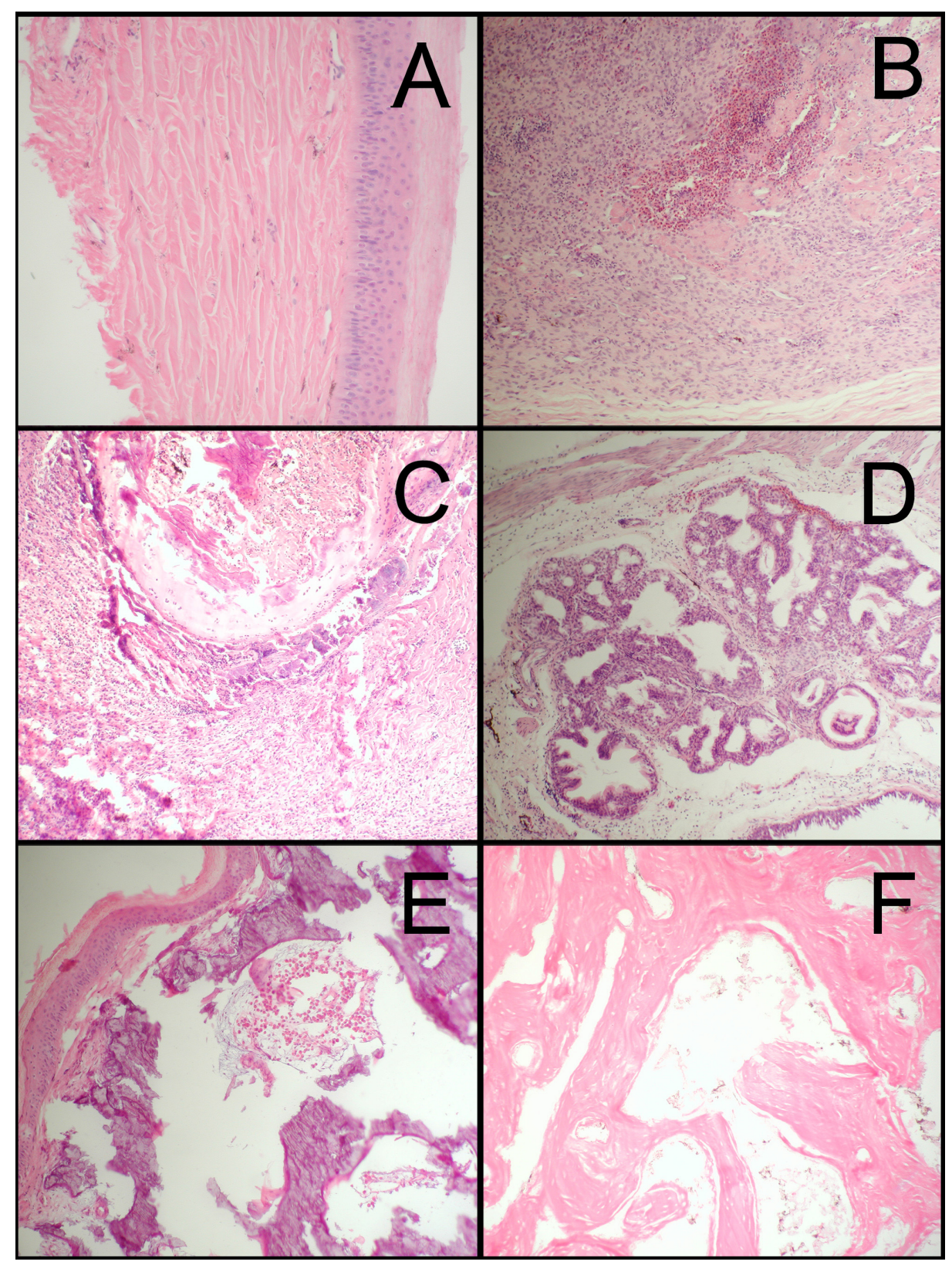

Fig. 2A. Absence of melanophores on the skin, leukoplakia. Haematoxylin and eosin $(\mathrm{HE}), \times 200$. $B$. Accumulation of erythrocytes, cellular debris and heterophilic granulocytes, haemorrhagicnecrotic dermatitis. HE, $\times 100$. C. Diffuse accumulation of heterophilic granulocytes in the skin, purulent-like dermatitis. $D$. Proliferation of the secretory cells of the lacrimal gland, adenoma. $\mathrm{HE}, \times 100 . E$. Osteolitic changes of the plastron with necrotic detritus and heterophilic granulocytes accumulation. HE, $\times 100 . F$. Reduction of the bone matrix of the plastron, osteoporosis. HE, $\times 100$ 
Table 3

Most common lesions of the shell and skeletal system of European pond turtles from different natural habitats

\begin{tabular}{|c|c|c|c|}
\hline Finding & $\begin{array}{l}\text { Lake Ludas } \\
\qquad(\mathrm{n}=60)\end{array}$ & $\begin{array}{l}\text { Lake Palic } \\
\qquad(\mathrm{n}=80)\end{array}$ & $\begin{array}{l}\text { Lake Tresetiste } \\
\qquad(\mathrm{n}=10)\end{array}$ \\
\hline Necrosis of the plastron & $9 / 60$ & $23 / 80$ & $0 / 10$ \\
\hline Proliferation of the shell & $0 / 60$ & $3 / 80$ & $0 / 10$ \\
\hline \multicolumn{4}{|l|}{ Fracture of junction between } \\
\hline the plastron and carapace & $0 / 60$ & $3 / 80$ & $1 / 10$ \\
\hline Invasion of the shell with algae & $3 / 60$ & $15 / 80$ & $0 / 10$ \\
\hline Leukoderma & $4 / 60$ & $11 / 80$ & $0 / 10$ \\
\hline Panostitis & $1 / 60$ & $1 / 80$ & $0 / 10$ \\
\hline Osteoporosis & $2 / 60$ & $4 / 80$ & $0 / 10$ \\
\hline Aplasia of the paw & $0 / 60$ & $2 / 80$ & $0 / 10$ \\
\hline Hypoplasia of the phalanx & $0 / 60$ & $4 / 80$ & $0 / 10$ \\
\hline Anomaly of the tail & $2 / 60$ & $10 / 80$ & $0 / 10$ \\
\hline Degenerative changes of the shell & $5 / 60$ & $12 / 80$ & $0 / 10$ \\
\hline Chondroma in the tarsal region & $0 / 60$ & $1 / 80$ & $0 / 10$ \\
\hline Turtles with no lesions & $38 / 60$ & $10 / 80$ & $1 / 10$ \\
\hline
\end{tabular}

Reptiles, among them turtles, are diagnosed with different skin, shell and bone lesions (Mader, 2006). The most prominent macroscopic lesions in our study were found on the plastron and carapace. Necroses of the shell were found mostly on the plastron $(21.33 \%)$ and less frequently we found fractures which were located usually in the junction of the plastron and carapace $(2.67 \%)$. In most cases, fractures were the result of mechanical injuries. European pond turtles live in freshwater areas, including ponds, lakes and slow-moving streams. In spite of the fact that these turtles search for habitats in shallow, fertile areas with adequate food supplies and minimal predators, they are usually endangered species (Bodie, 2001). Healing processes of shell traumas were a common finding. Depending on the acting force, these traumas were fissures or even open fractures with emerging soft tissue structures. Furthermore, one of the most often described complications of open shell fractures is lethal serositis. In addition, it has been suggested that the risk of infection in water turtles is greater than in terrestrial animals (Mader, 1992).

Due to the wet habitat, a number of bacteria (Aeromonas sp., Citrobacter sp., Enterobacter sp., Escherichia coli, Bacillus sp., Streptococcus sp., Proteus spp., Serratia sp. and Salmonella sp.) can invade the organism via mechanical lesions of the shell (Jacobson, 1992). Our results of bacteriological analysis in examined swabs showed that $76.67 \%$ of tested turtles were infected with some of ten different bacteria species. Aeromonas hydrophila (74\%), Citrobacter freundi (41.33\%), Serratia sp. (65.33\%) and Escherichia coli (65.33\%) were present both on the shell and the skin. Bacillus sp. (54\%), Enterobacter sp. (50\%) and 
Klebsiella sp. (32\%) were isolated only from the skin, while Proteus sp. (76.67\%) and Pseudomonas chitinovora (38.67\%) were isolated from the shell. Some tested animals had monoinfection, while others carried two or more bacterial species on their shell and skin; in some cases coinfection with Mucor sp. $(25.33 \%)$ or Fusarium sp. (8\%) was present. A total of $74 \%$ of the turtles examined were infected with Aeromonas hydrophila. Some members of the genus Aeromonas have been recognised as primary pathogens for cold-blooded as well as warm-blooded animal species (Gosling, 1996) and as opportunistic human pathogens. Strains of Aeromonas hydrophila are also pathogenic for turtles and frogs (Pasquale et al., 1994).

Regenerative processes in reptiles are poor as compared to those in amphibians. After limb amputation, bone structures do not regenerate, and only a skin stump is left behind. Changes in skeletal structures, which arise as a result of impaired mineral metabolism, are not rare in these reptiles. Softening and deformations of the shell (rickets, osteoporosis), should be regarded only as a part of more complex changes involving the whole skeleton (Mader, 1990). These changes are most often the result of disturbances of vitamin D and calcium phosphate metabolism. When the calcium level is relatively low, the body tries to compensate by taking calcium from the bones. This leads to a softening of the bones, making them susceptible to fractures and also leading to a deposition of fibrous tissue as the body tries to strengthen the bone in the absence of available calcium (Klemens, 2000). In this study, we found osteoporosis in $4 \%$ of the turtles examined.

Necrosis of the turtle's plastron was diagnosed in $21.33 \%$ of the turtles examined. The points of entry for infections were shell injuries in all cases. Bacteria isolated from the necrotic lesions were Aeromonas hydrophila (74\%), Citrobacter freundi (41.33\%), Serratia sp. (65.33\%), Pseudomonas chitinovora (38.67\%) and Proteus sp. (76.67\%). These bacteria are well known as the causative agents of haemorrhagic necrotising dermatitis. Citrobacter freundii has been pointed out as the causative agent of ulcerative changes in aquatic turtle's skin and shell (Cooper, 1992; Mader, 1993). Our results also confirmed the presence of Citrobacter freundii in a high number of the turtles examined, which suffered from necrotic and ulcerative changes of the plastron and skin $(41.33 \%)$. In cases of acute necrosis, there is an accumulation of fibrinous exudate in the bone tissue. The separation of necrotic bone tissue occurs as a result of resorption and rejection processes. The necrotic bone tissue is regularly demarcated from the surrounding healthy tissue (Cooper, 1992).

Mycoses are often described to be the cause of shell necrosis. Fungal infections appear as white flaky spots (white spot disease), and are more common in pond than in sea turtles. The most frequent fungi causing health problems in turtles are Mucor sp., Aspergillus sp., Fusarium, Microsporum sp., Saprolegnia sp., Trichophyton sp. and Candida sp. (Jacobson, 1992). Our results indicated 
that some of the turtles examined, originating from natural water habitats, were infected by Mucor sp. (25.33\%) and/or Fusarium sp. (8\%). As the isolated fungi originated from surfaces also infected with bacteria, it is unclear if they were pathogens or contaminants. It is already well known that a number of fungi are true pathogens of mammals but it is still unclear if they are pathogens of reptiles. Infection of sea turtles by fungi has been regarded as opportunistic, caused by normally saprophytic organisms that invade the tissues strictly under certain circumstances (Mader, 2006).

In the animals examined, the predominant skin lesion was purulent-like dermatitis (10\%). Enterobacter sp. and Klebsiella sp. were often isolated from this skin lesion. Similar results were obtained by other authors as well (Jacobson, 1992; Mader, 1993). Salmonella sp. was detected in $28.67 \%$ of the cloacal swabs tested. Particular attention should be paid to Salmonella sp. because of its possible role in humans (Dessi et al., 1992).

Furthermore, reptiles including turtles are being diagnosed with tumours at an increasing rate (Gál et al., 2006; Gál et al., 2009; Gál et al., 2010). Neoplastic changes of reptiles represent a new field of interest for many scientists. Neoplastic tissue proliferation was observed in two $(1.33 \%)$ of the turtles examined, both originating from Lake Palic. These neoplasms were diagnosed as adenoma of the lacrimal gland and chondroma of the tarsal region, respectively.

Growth of algae on the skin and shell was recorded in $12 \%$ of the turtles examined. Algae in polluted waters have a symbiotic nature but can cause flaking and deformations of the scute (Marcus, 1981). Colonisation by algae, which could also be one of the indicators of water pollution, was observed on the shell of some turtles from Lakes Palic and Ludas, unlike on turtles from Lake Tresetiste. Similar problems have been already described in other habitats (Wallach, 1975; Stuart, 1990). Nowadays, around the Palic and Ludas water habitats a number of villages are present, as well as some country cottages with concurrent intensive agriculture and livestock production burdened with the excessive use of agrochemicals. Waste water is discharged into the above-mentioned habitats without prior purification. Also, at the end of the 20th century the intensive industry in Subotica (the biggest city nearby Lake Palic and Lake Ludas ) was the major polluter of these water habitats. Water quality analyses showed increased level of pollutants such as phosphorus, nitrogen, chlorine, etc. (Raičević et al., 2011). Lake Tresetiste is an artificial lake, which is watered by a dead end of the Keres stream. The dead end was created at the site of an old peat mine and subsequently filled by rain and underground waters. Despite the fact that there are no published data about the water quality of Lake Tresetiste, it is known that this lake is not directly polluted by waste waters, and there are not present settlements in the neighbourhood which could affect the natural habitat of pond turtles. In addition, we found that all turtles caught in Lake Tresetiste, unlike turtles caught in Lake Palic and Lake Ludas, were without detected pathological 
changes on their shell and skin. This fact could explain the possible influence of water pollution on the health status of pond turtles in the water habitats explored.

The results obtained in this study call attention to the possible effects of water pollution on the health status of European pond turtles. This paper describes and documents, for the first time, the most common health problems of European pond turtles (Emys orbicularis) from natural habitats in Serbia.

\section{Acknowledgements} III 46002.

This study was supported by the Ministry of Science, Republic of Serbia, Project

We would like to thank Professor Dusan Gledic for critical reading of the manuscript. The study was also sponsored by the TÁMOP-4.2.2.B-10/1 and TÁMOP-4.2.1.B11/2/KMR-2011-0003 projects of Hungary.

\section{References}

Bodie, J. (2001): Steam and riparian management for freshwater turtles. J. Env. Management 62, 443-455.

Cooper, J. E. (1992): Integumentum. In: Beynon, P. H., Lawton, M. P. C. and Cooper, J. E. (eds) Manual of Reptiles. British Small Animal Veterinary Association, Gloucestershire, England. pp. 73-79.

Dessi, S., Sanna, C. and Paghi, L. (1992): Human salmonellosis transmitted by a domestic turtle. Eur. J. Epidemiol. 8, 120-121.

Ezvedj, J. (2005): Examination of pathological changes in skin and skeletal system of European pond turtles from natural habitat. M. Sc. Thesis, FVM, Belgrade University. pp. 1-68.

Ficetola, G. F. and De Bernardi, F. (2006): Is the European 'pond' turtle Emys orbicularis strictly aquatic and carnivorous? Amphibia-Reptilia 27, 445-447.

Frye, F. L. (1991): Reptile Care: An Atlas of Diseases and Treatments. Volume I. THF Publishing, Neptune City, New Jersey. pp. 281-312.

Frye, F. L. (1994): Clinical laboratory sample collection and processing. Proc. North Am. Vet. Conf. 8, 869.

Gál, J., Demeter, Z., Palade, E. A., Rusvai, M. and Géczy, Cs. (2009): Harderian gland adenocarcinoma in a Florida red bellied turtle (Pseudoemys nelsoni) - Case report. Acta Vet. Hung. 57, 275-281.

Gál, J., Mándoki, M., Sátorhelyi, T. and Jakab, Cs. (2010): In situ complex adenocarcinoma on the femoral part of the hindlimb in an Asian leaf turtle (Cyclemus dentata). Acta Vet. Hung. $\mathbf{5 8 ,}, 431-440$.

Gál, J., Szabó, Gy., Jakab, Cs., Géczy, Cs. and Sátorhelyi, T. (2006): Adenocarcinoma with squamous metaplasia in the parathyroid gland of Spur-thighed Tortoise (Testudo graeca) [in Hungarian, with English abstract]. Magyar Állatorvosok Lapja 128, 632-637.

Garner, M. M., Hernandez-Divers, S. M. and Raymond, J. T. (2004): Reptile neoplasia: a retrospective study of case submission to a specialty diagnostic service. Vet. Clin. Exot. Anim. Pract. 7, 653-671.

Gosling, P. J. (1996): Aeromonas species in disease of animals. In: Austin, B., Altwegg, M., Gosling, P. J. and Joseph, S. (eds) The Genus Aeromonas. Wiley, New York. pp. 175-196. 
Holland, C. D. (1994): The Western Pond Turtle; Habitat and History, 1993-1994 Final Report. DOEIBP-62137-1, Oregon Department of Fish and Wildlife, Portland, OR, United States.

Jacobson, E. R. (1992): Reptile dermatology. In: Kirk, R. W. and Bonagura, J. D. (eds) Kirk's Current Veterinary Therapy XI. Small Animal Practice. W. B. Saunders, Philadelphia. pp. $1204-1210$.

Klemens, W. M. (2000): Turtle conservation. Smithsonian Institute Press, Washington, D.C. 344 pp.

Mader, D. (1990): Metabolic bone disease in captive reptiles. The Vivarium 2, 12.

Mader, D. (1992): Shell repair in turtles and tortoises. The Vivarium 4, 9.

Mader, D. (1993): Common reptilian bacteria: What are they and what is their significance? The Vivarium 4, 27.

Mader, D. (2006): Reptile Medicine and Surgery. Chapter 19. Saunders-Elsevier, St. Louis, Missouri.

Marcus, C. L. (1981): Veterinary Biology and Medicine of Captive Amphibians and Reptiles. Lea and Febiger, Philadelphia. 239 pp.

Mitrus, S. (2006): Fidelity to nesting area of the European pond turtle, Emys orbicularis (Linnaeus, 1758). Belgian J. Zool. 136, 25-30.

Pasquale, V., Baloda, S. B., Dumontet, S. and Krovacek, K. (1994): An outbreak of Aeromonas hydrophila infection in turtles (Pseudemis scripta). Appl. Environ. Microbiol. 60, 1678-1680.

Raičević, V., Božić, M., Rudić, Ž., Lalević, B. and Kiković, D. (2011): The evolution of the eutrophication of the Palić Lake (Serbia). Afr. J. Biotechnol. 10, 1736-1744.

Scheren, P. A. G. M., Zanting, H. A. and Lemmens, A. M. C. (2000): Estimation of water pollution sources in Lake Victoria, East Africa: application and elaboration of the rapid assessment. methodology. J. Environ. Manage. 58, 235-248.

Sondergaard, M., Jensen, J. P. and Jeppesen, E. (2003): Role of sediment and internal loading of phosphorus in shallow lakes. Hydrobiologia 506/509, 135-145.

Stuart, J. S. (1990): Anaerobic bacterial infections in reptiles. J. Zoo Wildl. Med. 21, 180-184.

Trakimas, G. and Sidaravicius, J. (2008): Road mortality threatens small northern populations of the European pond turtle, Emys orbicularis. Acta Herpetol. 3, 161-166.

Wallach, J. D. (1975): The pathogenesis and etiology of ulcerative shell disease in turtles. J. Zoo Anim. Med. 6, 11-13. 